\title{
Some in-vitro comparisons of synovial cells dispersed by tryspin from rheumatoid and nonrheumatoid synovium
}

\author{
B. J. CLARRIS, ${ }^{1}$ J. R. E. FRASER, ${ }^{1}$ AND J. FERGUSON STANLEY ${ }^{2}$ \\ From the ${ }^{1}$ University of Melbourne, Department of Medicine, Royal Melbourne Hospital, Parkville, \\ Victoria 3050, Australia, and the ${ }^{2}$ Commonwealth Serum Laboratories, 45 Poplar Road, Parkville, \\ Victoria 3052, Australia
}

SUMMARY Life spans, growth rate, glucose utilisation, response to hydrocortisone, and intracellular activity of lysosomal $\mathrm{N}$-acetyl- $\beta$-glucosaminidase of rheumatoid synovial cells in culture were compared with these properties in nonrheumatoid synovial cells. Except for a small group of RA cells derived from tissue explants, the cells were all isolated by trypsinisation of synovial tissue, either within intact joints or after synovectomy. Cell lines were established by passaging with trypsin. In a study of 56 nonrheumatoid and 24 rheumatoid synovial lines isolated during a 7 -year period the latter were found to have a shortened mean life expectancy in culture, though there was wide variation between individual lines. This is in agreement with reported findings from untrypsinised explant-derived synovial lines. However, in the present study mean multiplication rates were identical for nonrheumatoid and rheumatoid synovial cells, and no clear differences could be demonstrated for the other properties studied. No correlation could be found between the life spans of synovial cell lines and the age of the cell donors, whether from rheumatoid or nonrheumatoid sources. Rheumatoid synovial cells isolated from intact joints were notable for especially high proportions of macrophage-like cells and suppression of fibroblasts. In most cases cell lines could not be established from these rheumatoid primary cultures, and in others the lines were short-lived. Early association with relatively high proportions of macrophage-like cells in rheumatoid cultures might thus be important in influencing the establishment and behaviour of synovial cell lines.

Various differences have been reported in cells cultured from rheumatoid synovium compared with nonrheumatoid synovial cells. In analyses of the earlier studies ${ }^{12}$ a number of possible explanations were considered, including the presence of occult viruses in rheumatoid synovial tissue. However, the explanation of the differences has not been elucidated experimentally.

In general the apparently disease-specific properties of rheumatoid synovial cells have been found in cultures derived from untrypsinised explants of tissue removed during surgery or by biopsy. To obtain pure cultures of synovial intimal cells from explants careful dissection of the tissue is required, and less demanding procedures have been sought from time to time. Cells can be stripped enzymically from synovial tissue by trypsinisation, either within

Accepted for publication 19 June 1980 Correspondence to Dr B. J. Clarris. the intact joint ${ }^{3}$ or from material scraped from the intimal surface. ${ }^{4}$ In both cases the cells settle evenly over the culture surface, and there is usually a comparatively short lag phase and rapid growth to confluency. ${ }^{5}$

In our early experiences with synovial cells obtained by these enzymic methods the behaviour of rheumatoid and nonrheumatoid cultures was remarkably similar in all readily observable features. Since this differed from reports on explant-derived synovial cells, it was felt that the initial impression warranted further investigation. The present comparison was based on several features in which differences seemed conclusive according to published work on untrypsinised synovial cells from explants of rheumatoid and nonrheumatoid tissues. These included life spans, growth rates, uptake of glucose, response to hydrocortisone, and intracellular levels of the lysosomal enzyme $\mathrm{N}$-acetyl- $\beta$-glucosaminidase. 
This confirmed that the behaviour of the trypsindispersed rheumatoid and nonrheumatoid synovial cells was similar except for a reduced life expectancy of the former. However, rheumatoid cells from intact joints formed a distinctive group from which explanations of the findings in this study might be inferred.

\section{Materials and methods}

\section{CELL CULTURE}

Nonrheumatoid (NRA) synovial cells were isolated by trysinisation of intact joints of cadavers or amputated legs. ${ }^{3}$ Trypsin was $0 \cdot 25-0.3 \%$ in $\mathrm{Ca}^{+}+1$ $\mathrm{Mg}^{++}$-free Dulbecco phosphate-buffered saline (PBS), and total exposure was usually less than 30 min. One series of rheumatoid (RA) cultures was obtained by gently scraping the intimal surface of excised synovium with a scalpel and trypsinising the released material. Conditions of trypsinisation were similar to those used in the intact NRA joints. Some explant cultures were also prepared from pieces of rheumatoid synovium. In a later series RA synovial cells were isolated from intact joints of living subjects by a slight modification of the trypsinwashout procedure used for NRA cultures.

Primary cultures were grown in chemically defined medium (Medium 199-M199 or Eagle's basal medium-EBM) supplemented with $20 \%$ (v/v) fetal bovine (FS) and $20 \%$ human (HS) serum. The defined media, FS, trypsin, and salt solutions (PBS, Hanks's balanced solution-HBSS) were obtained from Commonwealth Serum Laboratories, Parkville, Victoria. Human serum was prepared aseptically from fasting, nonrheumatoid donors. Except where otherwise indicated, all sera were heatinactivated $\left(56^{\circ} \mathrm{C}\right.$ for $\left.30 \mathrm{~min}\right)$. 'Cell lines' were established by passaging confluent monolayers with $0.25 \%$ trypsin solution. After the first or second passage the proportion of each serum in the medium was reduced to $10 \%$.

\section{LIFE SPANS}

Synovial cells were cultured in standardised conditions from isolation until the onset of senescence. This was judged by characteristics previously found to signify changes in karyotype, ${ }^{6}$ and the end point was taken as the passage after which these changes in growth rate and culture morphology occurred. It is emphasised that this end point does not indicate death of the cultures, since they can often be maintained viable but more or less static for months afterwards. During passaging the cultures were split 1:2. No corrections were made for losses of cells during trypsinisation.
OTHER OBSERVATIONS

Multiplication rates. Four pairs of cultures isolated within 7 days of one another were selected for direct comparison between RA and NRA cells. These were cultivated in identical media before the experiments, placed at adjacent sites in the incubator, and subcultured by identical procedures. At various passages during their life histories cell growth rates were formally estimated in replicate cultures with precautions fully described elsewhere. ${ }^{7}$ Glucose consumption was calculated from levels measured in fresh and spent medium with a Technicon (R) Autoanalyzer.

$N$-acetyl- $\beta$-glucosaminidase. Aliquots of the trypsin suspensions used for cell counts were centrifuged, drained, and frozen at $-70^{\circ} \mathrm{C}$. The intracellular activity of the enzyme was determined in cell lysates as described previously. ${ }^{8}$

\section{Results}

\section{LIFE SPANS}

As a first step a 'single blind' comparison was carried out using 8 NRA and 7 RA synovial lines (series I). After the first or second passage cultures from each were coded and transferred to the Cell Culture Laboratory at the Commonwealth Serum Laboratories, where they were cultivated until senescence as unknowns by one of the authors (J.F.S.). The medium for these cultures was M 199 supplemented with $20 \%$ unheated FS. The same lines were also followed simultaneously in the original laboratory. All were found to be free of mycoplasmas by both direct culture on agar $^{9}$ and isotope labelling with uridine and uracil. ${ }^{10}$ In the coded cultures no differences could be found between NRA and RA synovial lines, either in life spans or nett growth rates (Table 1), and inclusion of hydrocortisone in the culture media produced no significant effect on the life spans in either group (Table 2). Results from the independent laboratories correlated significantly $(r=0.65, P<0.05$; comparison based on numbers of population doublings).

In view of the small size of the first trial and the difference in outcome from earlier published reports

Table 1 Life spans of coded synovial cell lines (series $I^{*}$ )

\begin{tabular}{lllllll}
\hline Source No. & \multicolumn{2}{l}{ Life spans } & & $\begin{array}{l}\text { Interval } \\
\text { (days/ } \\
\text { passage) }\end{array}$ \\
\cline { 2 - 6 } & & Days & & Passages & & \\
\cline { 2 - 6 } & & Mean $\pm S D$ & Range & Mean $\pm S D$ & Range & \\
\hline RA & 7 & $112 \cdot 6 \pm 36 \cdot 9$ & $45-172$ & $16 \cdot 1 \pm 4 \cdot 7$ & $6-21$ & $7 \cdot 0$ \\
NRA 8 & $117 \cdot 1 \pm 24 \cdot 7$ & $84-160$ & $16 \cdot 6 \pm 4 \cdot 1$ & $12-24$ & $7 \cdot 1$ \\
\hline
\end{tabular}

*Defined in 'Results' section of text. 
Table 2 Effect of hydrocortisone on life spans of synovial cells in series $I$

\begin{tabular}{lllll}
\hline $\begin{array}{l}\text { Experi- } \\
\text { ment }\end{array}$ & $\begin{array}{l}\text { Rheumatoid } \\
\text { Final doubling number }\end{array}$ & \multicolumn{2}{l}{$\begin{array}{l}\text { Nonrheumatoid } \\
\text { Final doubling number }\end{array}$} \\
\cline { 2 - 5 } & Control & Hydrocortisone* & Control & Hydrocortisone* \\
\hline 1 & 21 & $21(17)^{*}$ & 28 & $19(13)$ \\
2 & 16 & $16(13)$ & 17 & $14(9)$ \\
3 & 18 & $24(5)$ & 25 & $24(8)$ \\
4 & 6 & $6(3)$ & 15 & $11(3)$ \\
5 & - & - & 17 & $17(13)$ \\
\hline
\end{tabular}

*Hydrocortisone $=$ hydrocortisone sodium succinate (Glaxo); final concentration $=10 \mu \mathrm{g} / \mathrm{ml}$. Figures in brackets indicate doubling number at which cortisol was added to medium.

on life spans of NRA and RA synovia! cells it was decided to extend the study. Cultures from each isolation were set aside from stocks and cultured so far as possible in a standardised manner until the onset of senescence. A total of 56 NRA and 24 RA lines was examined over a 7 -year period (series II). This extended study revealed a reduced life expectancy in RA synovial cells (Table 3 ). Premature senescence was strikingly accentuated in a later series of RA cultures isolated from intact joints, and the features of this series are discussed separately in a later section.

Distributions of life spans for the 2 classes of cells in series II are illustrated in Fig. 1. All grew to confluence in the primary phase and were therefore passaged at least once. The modal value for both NRA and RA lines was 9 passages. In the NRA group the life spans showed a normal pattern of distribution round the modal value with a marked skewness to the right. More than $23 \%$ of the NRA lines survived beyond the 15 th passage. The distribution of life spans was more confined in the RA group; none persisted beyond passage no. 16, and $17 \%$ became senescent after only 1 or 2 passages. Before senescence growth rates in both groups were variable, but mean intervals per passage over the entire life span were virtually identical despite the wide difference in mean life spans (Table 3). Growth rates measured formally in paired cultures (Table 4) showed no consistent differences between the 2 groups.

Table 3 Life spans of uncoded synovial cell lines (series $I^{*}$ )

\begin{tabular}{lcl}
\hline & $N R A$ & $R A$ \\
\hline Total & 56 & 24 \\
Life spans: & & \\
Days (range) & $149.4 \pm 105 \cdot 7(29-394)$ & $75 \cdot 8 \pm 47 \cdot 6(17-198)$ \\
Passages (range) & $16 \cdot 0 \pm 11 \cdot 2(1-48)$ & $8 \cdot 4 \pm 4 \cdot 9(1-16)$ \\
Days/passage & $9 \cdot 4$ & $9 \cdot 0$ \\
\hline
\end{tabular}

*Defined in 'Results' section of text.

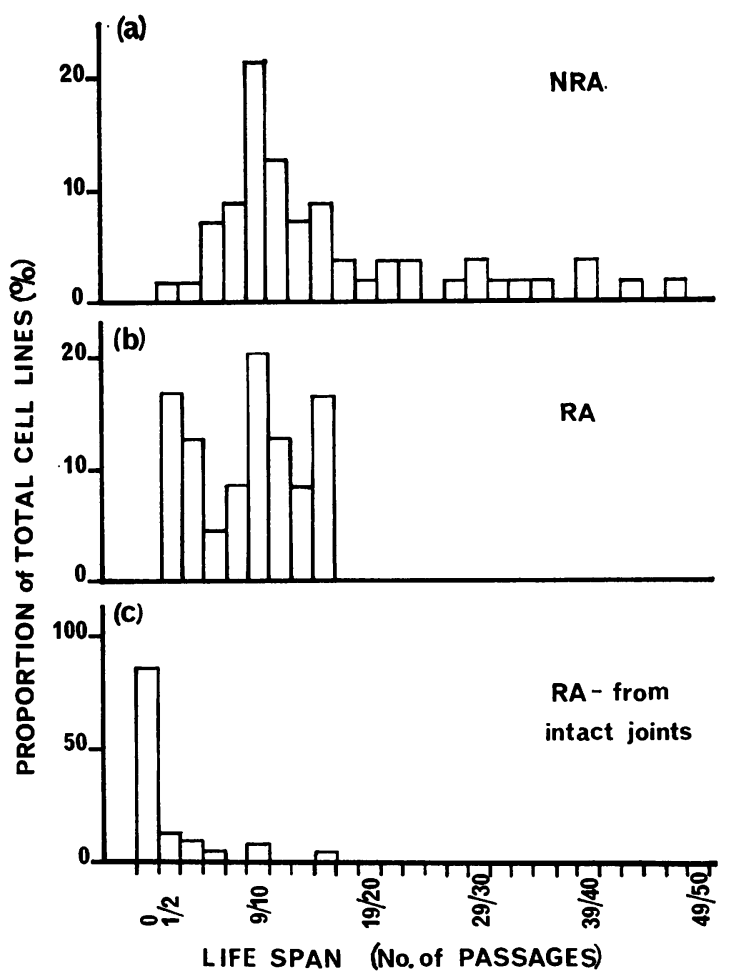

Fig. 1 Distributions of life spans of synovial cells: (a) NRA lines of series II; (b) RA lines of series II;

(c) $R A$ cultures from intact joints. Bars denote proportions of the total with the life spans indicated directly beneath (life spans grouped into pairs). Note the high proportion of $R A$ cultures from intact joints which failed to reach confluence in the primary phase.

The mean duration of the primary phase for NRA lines of series II was virtually the same as for the RA lines $(10 \cdot 1$ and $11 \cdot 1$ days respectively). Fifty-three $(94.6 \%)$ of the NRA lines and $18(75 \%)$ of the RA lines were passaged for the first time within 14 days of isolation, though in some cases confluence was reached even earlier: $18(32 \cdot 1 \%)$ of the NRA and 7 $(29.2 \%)$ of the RA lines were passaged 8 days (or less) after harvesting from the tissue. The duration of the primary phase was a poor predictor of later growth rate, since correlation coefficients for time to the first passage compared with time taken for the subsequent 4 passages were 0.02 and 0.01 for NRA and RA lines respectively.

In addition to series II, 3 explant-derived RA cultures were also examined. The mean life span of these was 132 days (range $=55$ to 231 days); 14 passages (range $=5$ to 27 ); interval $=9.4$ days per passage; that is, the mean growth rate was the same as for trypsin-dispersed NRA and RA lines. 
Table 4 Growth, glucose consumption and intracellular $N$-acetyl- $\beta$-glucosaminidase activity of pairs of rheumatoid and nonrheumatoid synovial cell lines

\begin{tabular}{|c|c|c|c|c|c|c|c|}
\hline Expcriment & Cell line & $\begin{array}{l}\text { Time in } \\
\text { culture (days) }\end{array}$ & $\begin{array}{l}\text { No. of } \\
\text { passages }\end{array}$ & $\begin{array}{l}\text { Initial count } \times 10^{-4} \\
\text { Mean } \pm S D\end{array}$ & $\begin{array}{l}\operatorname{MGT}(a) \\
(\text { days })\end{array}$ & $\begin{array}{l}N \text {-acetyl- } \beta \text {-glucose } \\
\text { aminidase }(b) \\
\text { Mean } \pm S D\end{array}$ & $\begin{array}{l}\text { Glucose } \\
\text { consumption (c) }\end{array}$ \\
\hline 1 & $\begin{array}{r}\text { RA } 1 \\
\text { NRA } 1\end{array}$ & $\begin{array}{l}24 \\
28\end{array}$ & $\begin{array}{l}6(d) \\
7(d)\end{array}$ & $\begin{array}{l}5 \cdot 7 \pm 1 \cdot 2 \\
6 \cdot 2 \pm 0 \cdot 9\end{array}$ & $\begin{array}{l}7.9 \\
7.9\end{array}$ & $\begin{array}{l}433 \cdot 0 \pm 32 \cdot 6 \\
344 \cdot 7 \pm 8 \cdot 0\end{array}$ & $\begin{array}{l}1 \cdot 6 \\
1 \cdot 3\end{array}$ \\
\hline 2 & $\begin{array}{r}\text { RA } 2 \\
\text { NRA } 2\end{array}$ & $\begin{array}{l}27 \\
28\end{array}$ & $\begin{array}{l}4 \\
4\end{array}$ & $\begin{array}{l}10 \cdot 8 \pm 0 \cdot 3 \\
15 \cdot 1 \pm 0.4\end{array}$ & $\begin{array}{r}7 \cdot 0 \\
10 \cdot 7\end{array}$ & $\begin{array}{l}233 \cdot 2 \pm 2 \cdot 5 \\
314 \cdot 3 \pm 17 \cdot 6\end{array}$ & $\begin{array}{l}2 \cdot 6 \\
3 \cdot 0\end{array}$ \\
\hline 3 & $\begin{array}{r}\text { RA } 2 \\
\text { NRA } 2\end{array}$ & $\begin{array}{l}63 \\
64\end{array}$ & $\begin{array}{l}10 \\
10\end{array}$ & $\begin{array}{l}9 \cdot 7 \pm 0.3 \\
9 \cdot 2 \pm 0.7\end{array}$ & $\begin{array}{l}5 \cdot 7 \\
\text { No growth }\end{array}$ & $\begin{array}{l}421 \cdot 3 \pm 5 \cdot 9 \\
670 \cdot 8 \pm 14 \cdot 3\end{array}$ & $\begin{array}{l}5 \cdot 5 \\
8 \cdot 8\end{array}$ \\
\hline 4 & $\begin{array}{r}\text { RA } 3 \\
\text { NRA } 3\end{array}$ & $\begin{array}{l}28 \\
23\end{array}$ & $\begin{array}{l}4 \\
4\end{array}$ & $\begin{array}{l}9 \cdot 6 \pm 2 \cdot 1 \\
8 \cdot 7 \pm 1 \cdot 0\end{array}$ & $\begin{array}{r}15.6 \\
6.6\end{array}$ & $\begin{array}{l}406 \cdot 1 \pm 19 \cdot 1 \\
358 \cdot 7 \pm 8 \cdot 1\end{array}$ & $\begin{array}{l}3 \cdot 1 \\
2 \cdot 4\end{array}$ \\
\hline 5 & $\begin{array}{r}\text { RA } 4 \\
\text { NRA } 4\end{array}$ & $\begin{array}{l}17 \\
16\end{array}$ & $\begin{array}{l}3 \\
3\end{array}$ & $\begin{array}{l}5 \cdot 5 \pm 0 \cdot 3 \\
6 \cdot 6 \pm 0 \cdot 3\end{array}$ & $\begin{array}{l}5 \cdot 7 \\
7.5\end{array}$ & $\begin{array}{l}684 \cdot 3 \pm 20 \cdot 2 \\
819 \cdot 1 \pm 11 \cdot 2\end{array}$ & 3.0 \\
\hline
\end{tabular}

Culture medium was M 199 with $1_{0} \%$ FCS and $10 \% \mathrm{HS}$.

(a) $\mathrm{MGT}=$ Mean generation time $=-\frac{\log _{10} 2 \times \text { time }}{\log _{10}(\text { final count })-\log _{10} \text { (initial count) }}$.

(b) This is expressed as pgm $p$-nitrophenol released from $3.6 \mathrm{mM}$-nitrophenyl phosphate-2-acetamido-2-deoxy- $\beta$-D-glucopyranoside per cell per hour incubation at $35^{\circ} \mathrm{C}$.

(c) ngm per cell per day.

(d) Within the first 4 days it was necessary to passage the NRA line, and the number of passages thus differs by 1.

\section{EFFECT OF AGE OF CELL DONOR ON}

\section{LIFE SPANS OF SYNOVIAL CELL LINES}

As would be expected, the mean age of the NRA donors was considerably higher than that of the RA donors, since, with the exception of 4 amputees, the former were deceased when the cells were isolated. The mean for NRA donors was 58.9 years and 18 were 70 or over. All of the RA donors were less than 70 and the mean age was $46 \cdot 4$ years.

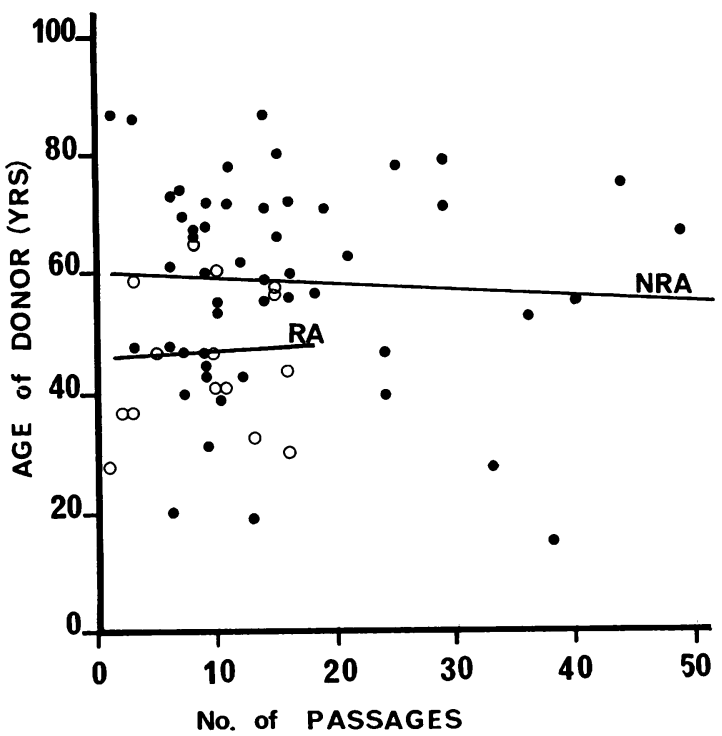

Fig. 2 Life spans of NRA and RA cell lines compared with age of the cell donor: NRA (closed circles); $R A$ (open circles). Correlations were not significant in either group $\left(r_{N R A}=0.07 r_{R A}=0.05\right)$.
There was, however, no discernible relationship between life spans and age of the cell donors in either group (Fig. 2).

\section{LIFE HISTORIES OF RA SYNOVIAL CELLS}

FROM INTACT JOINTS

Some peculiarities of RA cells isolated in this manner were described previously. ${ }^{4}$ In the present context a particularly striking feature was the failure of the majority of cultures to follow the expected pattern of development in the primary phase. In 41 of the 58 cultures in this series (Table 5) fibroblastlike cells either remained static in number after the initial attachment and spreading, or gradually disappeared. Growth could not be stimulated, even with serum concentrations of $50 \%$, a level found previously to produce maximal stimulation of growth in NRA synovial cells. ${ }^{7}$ In most of these static cultures the substratum became progressively covered by rounded, macrophage-like cells, many

Table 5 Life histories of synovial cells isolated from intact knee joints of patients with rheumatoid arthritis

\begin{tabular}{|c|c|c|c|c|}
\hline \multirow[t]{2}{*}{$\begin{array}{l}\text { Life span (a) } \\
\text { (No. of passages) }\end{array}$} & \multirow[t]{2}{*}{$\begin{array}{l}\text { No. of } \\
\text { cultures }\end{array}$} & \multirow[t]{2}{*}{$\begin{array}{l}\% \text { of } \\
\text { total }\end{array}$} & \multicolumn{2}{|c|}{$\begin{array}{l}\text { Life span (a) } \\
\text { (days) }\end{array}$} \\
\hline & & & Mean & Range \\
\hline $\begin{array}{l}0 \text { (b) } \\
1 \\
2 \\
3 \\
4 \\
5 \\
9 \\
10 \\
11 \\
\text { Total }\end{array}$ & $\begin{array}{r}41 \\
5 \\
1 \\
3 \\
2 \\
2 \\
1 \\
2 \\
1 \\
58\end{array}$ & $\begin{array}{r}70 \cdot 7 \\
8 \cdot 6 \\
1 \cdot 7 \\
5 \cdot 2 \\
3 \cdot 4 \\
3 \cdot 4 \\
1 \cdot 7 \\
3 \cdot 4 \\
1 \cdot 7\end{array}$ & $\begin{array}{r}19 \cdot 6 \\
31 \cdot 0 \\
38 \cdot 7 \\
34 \cdot 5 \\
60 \cdot 0 \\
66 \cdot 0 \\
93 \cdot 5 \\
126 \cdot 0\end{array}$ & $\begin{array}{l}13-27 \\
30-46 \\
32,37 \\
37,83 \\
79,108\end{array}$ \\
\hline
\end{tabular}

(a) As defined in Methods. (b) Cultures in which growth of fibroblastlike cells was suppressed indefinitely. 
of them greatly enlarged and frequently including numerous multinucleated cells. A second notable feature of these cultures was the premature senescence of the few cell lines which survived subcultivation (Fig. 1). Cell lines could be established from only 18 of the 58 primary cultures. The mean length of the primary phase in these 18 cultures was $17 \cdot 1$ days (cf. 10.1 and $11 \cdot 1$ for NRA and RA lines of series II respectively). Only 8 of the 18 survived for 4 or more passages, whereas 5 others showed senescent changes after the first subcultivation. In the longest lived example the cell line became senescent after the 16th passage.

GLUCOSE CONSUMPTION AND INTRACELLULAR LYSOSOMAL ENZYME ACTIVITY

As mentioned, no consistent differences could be found when growth of paired NRA and RA synovial lines was compared (Table 4). Glucose consumption and intracellular activity of $\mathrm{N}$-acetyl- $\beta$-glucosaminidase were measured in the same experiments, and there were also no consistent differences between NRA and RA lines.

\section{EFFECT OF HYDROCORTISONE ON GROWTH OF SYNOVIAL CELLS}

Castor and Dorstewitz ${ }^{11}$ noted decreased mitotic stimulation of RA synovial cells by hydrocortisone compared with their NRA counterparts. In the present study RA synovial lines derived from explants were compared with NRA lines from trypsinised joints of cadavers. Hydrocortisone base (Sigma Chemicals) was included in concentrations of $0 \cdot 1-1.5 \mu \mathrm{g} / \mathrm{ml}\left(2 \cdot 8 \times 10^{-7}-4.2 \times 10^{-6} \mathrm{M}\right)$. The effects were small and there was no consistent trend in either group (Table 6).

Table 6 Effect of hydrocortisone on growth of NRA and $R A$ synovial cell lines

\begin{tabular}{|c|c|c|c|c|c|}
\hline \multirow[t]{2}{*}{$\begin{array}{l}\text { Cell line } \\
\text { (a) }\end{array}$} & \multirow[t]{2}{*}{$\begin{array}{l}\text { Passage } \\
\text { no. }\end{array}$} & \multicolumn{4}{|c|}{ 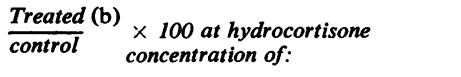 } \\
\hline & & 0.01 & 0.1 & 0.5 & $1.5 \mu \mathrm{g} / \mathrm{ml}$ \\
\hline $\begin{array}{l}79-3 R \\
79-3 R \\
79-3 R \\
79-4 R \\
79-6 R \\
79-12 N \\
79-12 N \\
79-13 N \\
79-14 N \\
79-15 N\end{array}$ & $\begin{array}{r}1 \\
4 \\
13 \\
1 \\
4 \\
1 \\
2 \\
2 \\
2 \\
2\end{array}$ & $\begin{array}{r}- \\
\overline{-} \\
98 \cdot 3 \\
106 \cdot 9 \\
102 \cdot 7 \\
118 \cdot 5 \\
- \\
96 \cdot 3 \\
102.7 \\
86.7\end{array}$ & $\begin{array}{r}103 \cdot 8 \\
92 \cdot 8 \\
93 \cdot 6 \\
106 \cdot 7 \\
92 \cdot 6 \\
\\
97 \cdot 6 \\
94 \cdot 1 \\
92 \cdot 0 \\
84 \cdot 3\end{array}$ & $\begin{array}{r}93 \cdot 1 \\
88 \cdot 9 \\
91 \cdot 5 \\
107 \cdot 2 \\
98 \cdot 0 \\
117 \cdot 4 \\
97 \cdot 4 \\
92 \cdot 3 \\
86 \cdot 6 \\
85 \cdot 0\end{array}$ & $\begin{array}{l}83 \cdot 1 \\
86 \cdot 4 \\
- \\
- \\
126 \cdot 6 \\
97 \cdot 9 \\
- \\
-\end{array}$ \\
\hline
\end{tabular}

(a) $\mathbf{R}=$ rheumatoid, all derived from explants; $\mathbf{N}=$ nonrheumatoid, all derived from intact joints by trypsinisation. Cultures were grown in EMB $+10 \%$ FS for $48 \mathrm{~h}$ and counted with a Coulter counter. In all cases there was a net increase in cell numbers, in both controls and hydrocortisone-treated cells. (b) Final cell counts.

\section{Discussion}

Life spans of cells in vitro can be influenced by variations in culture conditions which might easily pass unrecognised-for example, quality of commonly used constituents in media, such as fetal bovine serum. ${ }^{12}$ Early in the present study we attempted to minimise the effects of inapparent variations by standardising the composition of culture media, using RA and NRA lines paired with respect to time of isolation, and incorporating 'blind' assessment into the experimental design. Clearly, as suggested recently by Marsh et al., ${ }^{13}$ this would be ideal for all such comparisons, but in the long-term study it was necessary to modify the protocol because of rather formidable practical difficulties, particularly in simultaneous isolation of RA and NRA cultures. In any case the identical mean passage times of the RA and NRA lines of series II and the RA lines derived from explants virtually excluded influence of secular trends or variation in conditions of culture and indicated that there was no appreciable bias in decisions to passage or determine end points.

In the present investigation trypsin-dispersed RA synovial cultures derived from surgically excised tissue were found to have reduced mean life spans, but with wide variation. Indeed, the differences between these and the NRA lines were mainly due to early senescence of a few RA cultures and the skewed distribution of life spans in the NRA group, in which a small number showed exceptionally sustained proliferative capacity. In both groups most of the cell lines behaved similarly, which seems the most likely reason for the failure of the small single-blind study to confirm previously observed differences between the life spans of RA and NRA synovial cell lines. ${ }^{14}$ No differences could be found in growth rates either by simultaneous measurements on paired RA and NRA lines or from mean rates during the life histories. Furthermore, reported differences in glucose uptake and response to hydrocortisone $\mathrm{e}^{11}$ and in intracellular lysosomal enzyme activities ${ }^{15}$ could not be confirmed in the trypsin-dispersed RA and NRA synovial lines.

Residual effects of drugs or disease in cells from NRA donors might have reduced the life spans of cell lines to overlap those of RA cells. However, the behaviour of cells from accident cases was not distinctive, and no relationship was discernible between type of disease (Table 7) and subsequent features of cells in culture. Moreover, the rapid attachment and spreading on culture surfaces did not suggest any residual effect from anoxia. Most cultures were established within 4 hours of death or surgery, whereas some tissues, for example, human 
Table 7 Cause of death of nonrheumatoid donors of synovial cell lines

\begin{tabular}{lr}
\hline Condition & Number \\
\hline Stroke; other diseases of nervous & 10 \\
$\quad$ system & 6 \\
Subarachnoid haemorrhage & 1 \\
Aortic aneurism & 11 \\
Ischaemic heart disease & 2 \\
Chronic renal failure & 8 \\
Respiratory & 2 \\
Gastrointestinal & 2 \\
Diabetes & 3 \\
Accident & 1 \\
Alcoholic liver disease & 1 \\
Drug overdose & 5 \\
Unknown & 52 \\
Total &
\end{tabular}

Subjects with neoplasms of any kind or with recognisable arthritis were excluded.

arterial smooth muscle, ${ }^{16}$ retain normal function for much longer periods after removal from the body. Life spans in both groups of cells were independent of age of the donors, though a slight negative relationship, as observed in other tissues, ${ }^{17-19}$ might have been obscured in this study by the many extraneous influences associated with cell culture. Further elucidation of this problem would require cell cultures from much younger donors, and these are not easily available.

The key to understanding the behaviour of RA synovial cells in this and previous studies can most likely be found in the unusual behaviour of the RA cultures isolated from living subjects. This was quite distinct from that of cells from excised RA tissue or trypsinised NRA joints of cadavers. The most obvious difference lay in the much higher proportion of macrophage-like cells in the cultures from living RA joints, which probably reflects both the high proportion of type A synoviocytes at the surface of the inflammed intima ${ }^{20}$ and rapid inactivation of trypsin in the joint, even after extensive prerinsing (Robinson A, unpublished observations). As a consequence the number of fibroblast-like cells in these isolates might have been less than a threshold necessary for initiation of mitosis. ${ }^{21}$ However, there is evidence of inhibitory activity associated with RA macrophages, ${ }^{22}{ }^{23}$ and in this particular type of RA culture fibroblast-like cells may regress and disappear after initial establishment. The difference in behaviour of RA cells isolated by the 2 methods strongly suggests that macrophages in the rheumatoid synovium can cause early inhibition of fibroblast growth in culture and perhaps accelerate the processes or onset of senescence. Functional differences in RA cell lines might reflect persistence of CTAP stimulation ${ }^{24}$ due to prolonged association with activated macrophages, as demon- strated for blood leucocytes ${ }^{25}$ and an extract from platelets. ${ }^{26}$ This process might be initiated in vivo and accentuated in culture. Whereas the explant procedure introduces integrated tissue into the culture environment, trypsinisation promotes wide dispersal of cells, possibly reducing the intensity of interactions by reducing intracellular contacts. The foregoing observations do not preclude the possibility that latent or modified virus infection in the macrophage-like cells might also influence the behaviour of RA synovial cells in culture.

This work was supported by grants from the National Health and Medical Research Council of Australia. We thank $\mathrm{Mr}$ S. Murdoch and Mrs L. Malcolm for able technical assistance, and we gratefully acknowledge the assistance of orthopaedic surgical staff, particularly $\mathrm{Mr} \mathrm{K}$. Mills, for providing synovial tissue. Thanks are also due to Drs $\mathrm{C}$. Moran, A. Stockman, K. Boyden, and Mr A. Robinson for isolations of rheumatoid synovial cells from patients.

\section{References}

1 Smith C, Hamerman D. Significance of persistent differences between normal and rheumatoid synovial membrane cells in culture. Arthritis Rheum 1969; 12: 639-45.

2 Smith C A. Properties of synovial cells in culture J Exp Med 1971; 134: 306-12.

${ }^{3}$ Fraser J R E, Catt K J. Human synovial cell culture. Use of a new method in a study of rheumatoid arthritis. Lancet 1961 ; ii: 1437-9.

4 Clarris B J, Fraser J R E, Moran C J, Muirden K D. Rheumatoid synovial cells from intact joints. Morphology; growth and polykaryocytosis. Ann Rheum Dis 1977; 36: 293-301.

5 Fraser J R E, McCall J F. Culture of synovial cells in vitro. Ann Rheum Dis 1965; 24: 351-9.

6 Clarris B J, Fraser J R E. Relationship between chromosomal changes and alterations in the behaviour of a strain of human synovial cells during its life history in vitro. Ann Rheum Dis 1968; 27 : 597-603.

7 Clarris B J, Fraser J R E. The effects of homologous and heterologous whole serum upon multiplication of recentlyisolated human synovial cells in culture. Aust J Exp Biol Med 1967; 45: 549-60.

8 LeMarshall J, Fraser J R E, Muirden K D. Lysosomal activation by neutral saccharides in cell cultures of synovium. Ann Rheum Dis 1977; 36: 130-8.

9 MacGregor A, Ficorilli N. Determination of mycoplasma infection in cell cultures; How reliable is the uridine/ uracil uptake ratio method? Vet Microbiol 1978; 3: $167-8$.

10 Tomkins G A, MacGregor A, Pye D, Atkinson M. Rapid detection and isolation of mycoplasmas from cell cultures. Aust J Exp Biol Med 1975; 53: 257-63.

11 Castor C W, Dorstewitz E L. Abnormalities of connective tissue cells cultured from patients with rheumatoid arthritis. I. Relative unresponsiveness of rheumatoid synovial cells to hydrocortisone. J Lab Clin Med 1966; 68: 300-13.

12 Schneider E L, Braunschweiger K, Mitsui Y. The effect of serum batch on the in vitro life spans of cell cultures derived from old and young human donors. Exp Cell Res 1978; 115: 47-52. 
13 Marsh J M, Maini R N, Wiebkin O W, Dumonde D C. Rheumatoid and normal synovial tissue in longterm culture. Evidence of cell heterogeneity and an approach to quantition of populations and the effect of passage. $J$ Rheumatol 1978; 5: 148-61.

14 Bartfeld $H$. Rheumatoid arthritic and non-arthritic synovium in cell culture. Morphological observations, acridine orange, and fluorescent fraction II studies. Ann Rheum Dis 1965; 24: 31-9.

15 Goldfischer S, Smith C, Hamerman D. Altered acid hydrolase activities in rheumatoid synovial cells in culture. Am J Pathol 1968; 52: 569-75.

16 Jauernig R A, Moulds R F W. A human arterial preparation for studying the effect of vasoactive agents. Circ Res 1978; 42: 363-8.

17 Martin G M, Sprague C A, Epstein C J. Replicative life-span of cultivated human cells. Effects of donor's age, tissue and genotype. Lab Invest 1970; 23: 86-92.

18 Schneider E L, Mitsui Y. The relationship between in vitro cellular aging and in vivo human age. Proc Natl Acad Sci USA 1976; 73: 3584-8.

19 Bierman E L. The effect of donor age on the in vitro life span of cultured human arterial smooth-muscle cells. In Vitro 1978; 14: 951-5.

20 Ghadially F N, Roy S. Ultrastructure of Synovial Joints in Health and Disease. Butterworth, London: 1969: 28.

21 Earle W R, Sanford K K, Evans V J, Waltz H K, Shannon $J$ E Jr. The influence of inoculum size on proliferation in tissue cultures. US Natl Cancer Inst J 1951; 12: 133-53.

22 Palmer D G. Polykaryocytes and rheumatoid disease. $J$ $R$ Coll Physicians Lond 1971; 6: 33-40.

${ }^{23}$ Smith C A. Rheumatoid synovial cells in culture produce a growth inhibitor. Ann Rheum Dis 1978; 37: 187-9.

24 Castor C W. Connective tissue activation II. Abnormalities of cultured rheumatoid synovial cells. Arthritis Rheum 1971; 14: 55-66.

25 Castor C W, Yaron M. Leukocyte-connective tissue cell interaction. II. The specificity, duration and mechanism of interaction effects. Arthritis Rheum 1969; 12: 374-86.

${ }^{26}$ Castor C W, Ritchie J C, Scott M E, Whitney S L. Connective tissue activation XI. Stimulation of glycosaminoglycan and DNA formation by a platelet factor. Arthritis Rheum 1977; 20: 859-68. 